\title{
A new dimeric imidazole alkaloid plasmid conjugation inhibitor from Lepidium sativum
}

\section{Awo Afi Kwapong ${ }^{\text {a, }}$}

Paul Stapleton

\section{Simon Gibbons $\mathbf{s}^{\mathrm{a}, *}$}

simon.gibbons@ucl.ac.uk

aResearch Department of Pharmaceutical and Biological Chemistry, UCL School of Pharmacy, 29-39 Brunswick Square, London WC1N 1AX, United Kingdom

bepartment of Pharmaceutics and Microbiology, School of Pharmacy, University of Ghana, Ghana

${ }^{*}$ Corresponding author

\section{Abstract}

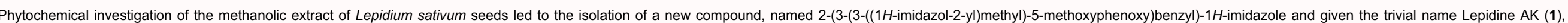

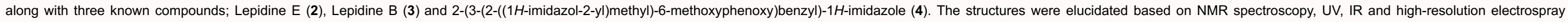

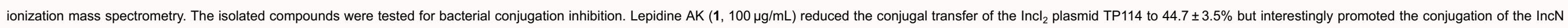
plasmid pKM101 to greater than $120 \%$.

Keywords: Dimeric; Imidazole; Lepidine; Plasmids; Conjugation

\section{Introduction}

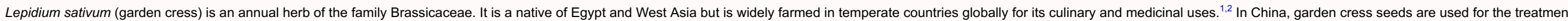

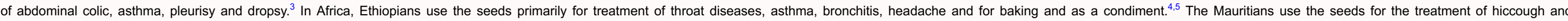

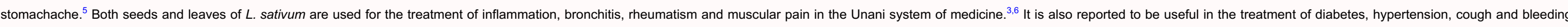

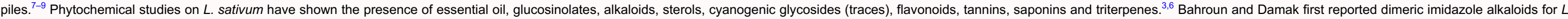
sativum seeds after which Meinhart Zenk's group isolated five additional analogues. ${ }^{10}$

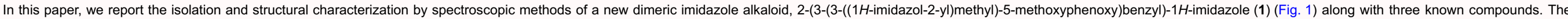
antibacterial and antifungal activitiesy and inhibition of bacterial conjugal transfer of plasmids of the isolated compounds are reported herein for the first time!

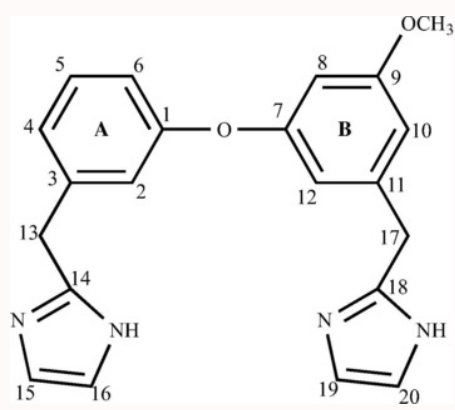




\section{Fig. 1 Structure and numbering of compound 1}

\section{Results and discussion}

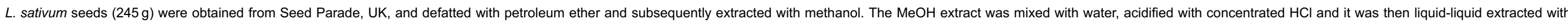

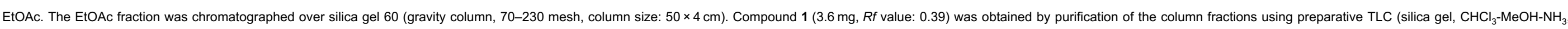
$90: 9: 1, \mathrm{~V} / \mathrm{v})$.

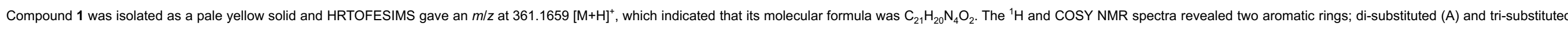

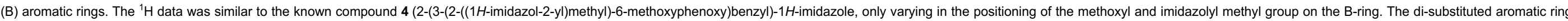

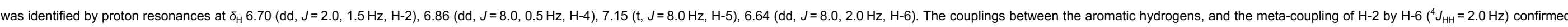

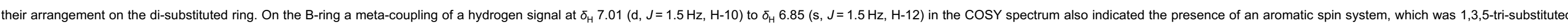

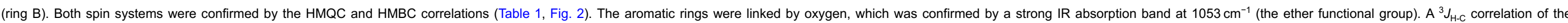

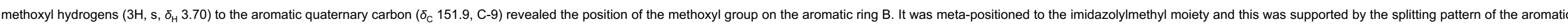

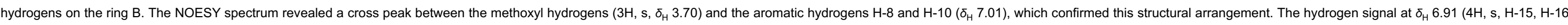

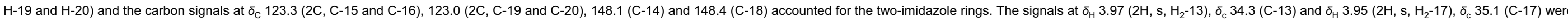

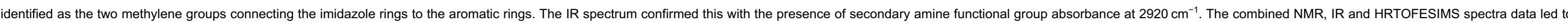

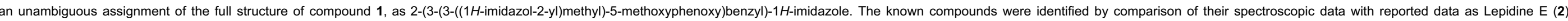
Lepidine B (3) and 2-(3-(2-((1H-imidazol-2-yl)methyl)-6-methoxyphenoxy)benzyl)-1H-imidazole (4) ${ }^{10}$

Table $1{ }^{1} \mathrm{H}(500 \mathrm{MHz})$ and ${ }^{13} \mathrm{C} \mathrm{NMR}(125 \mathrm{MHz})$ NMR data and $\mathrm{HMBC}$ correlations of 1 recorded in methanol- $d_{4}$.

\begin{tabular}{|c|c|c|c|}
\hline Position & $\delta_{\mathrm{C}}$, type & $\delta_{\mathrm{H}},(\mathrm{J}$ in $\mathrm{Hz})$ & HMBC \\
\hline 1 & 159.9, C & & \\
\hline 2 & $117.6, \mathrm{CH}$ & $6.70, \mathrm{dd}(2.0,1.5)$ & \\
\hline 3 & 141.0, C & & \\
\hline 4 & 123.3, CH & $6.86, \mathrm{dd}(8.0,0.5)$ & C-5 \\
\hline 5 & $130.6, \mathrm{CH}$ & $7.15, \mathrm{t}$ & C-1, C-3 \\
\hline 6 & 115.6, $\mathrm{CH}$ & $6.64, \mathrm{dd}(8.0,2.0)$ & \\
\hline 7 & 145.6, C & & \\
\hline 8 & $114.5, \mathrm{CH}$ & $7.01, \mathrm{~s}$ & C-9 \\
\hline 9 & 151.9, C & & \\
\hline 10 & $126.4, \mathrm{CH}$ & 7.01, d (1.5) & C-11 \\
\hline 11 & 132.5, C & & \\
\hline 12 & $123.0, \mathrm{CH}$ & $6.85, d(1.5)$ & \\
\hline 13 & $34.3, \mathrm{CH}_{2}$ & $3.97, \mathrm{~s}$ & C-2, C-3, C-4, C-14 \\
\hline 14 & 148.1, C & & \\
\hline 15 & $123.3, \mathrm{CH}$ & $6.91, \mathrm{~s}$ & C-14 \\
\hline 16 & 123.3, CH & $6.91, \mathrm{~s}$ & C-14 \\
\hline
\end{tabular}




\begin{tabular}{|c|c|c|c|}
\hline 17 & $35.1, \mathrm{CH}_{2}$ & $3.95, \mathrm{~s}$ & C-10, C-11, C-12, C-18 \\
\hline 18 & $148.4, \mathrm{C}$ & & \\
\hline 19 & 123.0, $\mathrm{CH}$ & $6.91, \mathrm{~s}$ & C-18 \\
\hline 20 & $123.0, \mathrm{CH}$ & $6.91, \mathrm{~s}$ & C-18 \\
\hline O-Me & $56.5, \mathrm{CH}_{3}$ & $3.70, \mathrm{~s}$ & C-9 \\
\hline
\end{tabular}

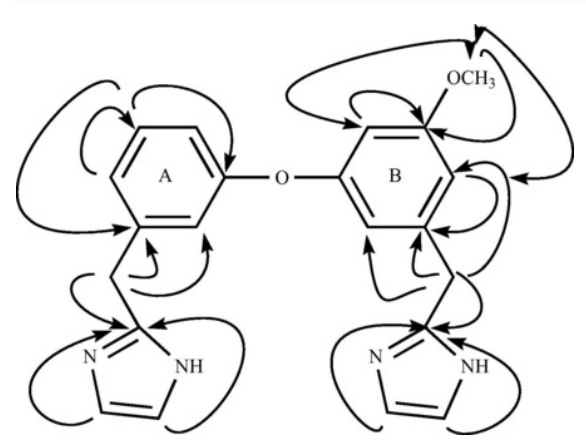

Fig. 2 Key HMBC (single-headed arrows) and NOESY (double-headed arrows) correlations of compound 1 .

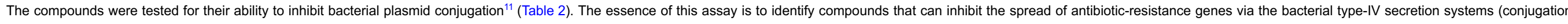

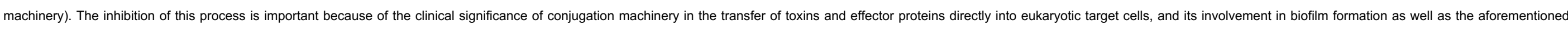
transfer of antibiotic-resistance genes among microorganisms. ${ }^{12,13}$

Table 2 The effect of the isolated dimeric imidazoles on conjugal transfer of plasmids pKM101 and TP114

\begin{tabular}{|c|c|c|c|c|c|c|c|}
\hline \multirow{2}{*}{$\begin{array}{l}\text { Conjugation pair } \\
\text { Donor }\end{array}$} & \multicolumn{5}{|c|}{ Compounds $(100 \mu \mathrm{g} / \mathrm{mL})$} & \multicolumn{2}{|c|}{ Controls } \\
\hline & Recipient & 1 & 2 & 3 & 4 & Novobiocin $(10 \mu \mathrm{g} / \mathrm{mL})$ & No drug \\
\hline pKM101a & ER1793c & $120 \pm 0.0$ & $31.0 \pm 7.0$ & $120 \pm 0.0$ & $28.0 \pm 5.0$ & - & $100.0 \pm 0.0$ \\
\hline TP114b & & $44.0 \pm 3.5$ & $26.0 \pm 4.0$ & $120 \pm 0.0$ & $23.5 \pm 4.0$ & $17.0 \pm 4.2$ & $100.0 \pm 0.0$ \\
\hline
\end{tabular}

The values represent the mean transfer frequency $(\%) \pm$ standard deviation of at least three independent experiments.

a E. coli strain WP2 bearing plasmid pKM101 (IncN; ampicillin-resistant).

${ }^{b}$ E. coli strain $\mathrm{K} 12$ J53-2 bearing plasmid TP114 (Incl2; kanamycin-resistant).

c E. coli strain ER1793, streptomycin resistant.

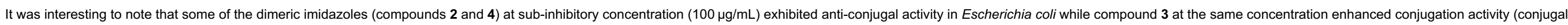
transfer frequency, greater than $120 \%$ ). With compound $\mathbf{1}$, the activity varied.

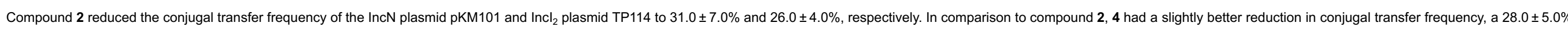

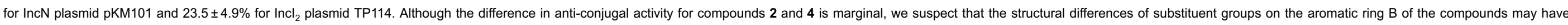

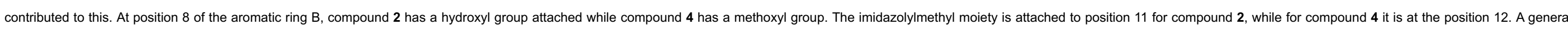

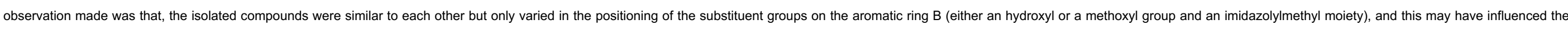
varied outcome of activity against the conjugal transfer of plasmids in $E$. coli. 


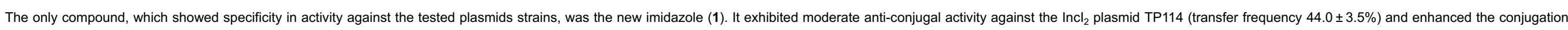

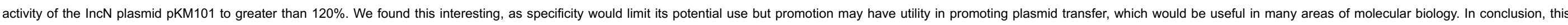

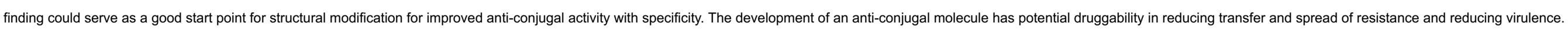

\section{Structure elucidation}

2-(3-(3-((1H-imidazol-2-yl)methyl)-5-methoxyphenoxy)benzyl)-1H-imidazole (compound 1).

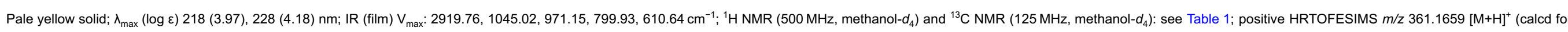
$\left.\mathrm{C}_{21} \mathrm{H}_{20} \mathrm{~N}_{4} \mathrm{O}_{2}, 361.1664\right)$.

\section{Acknowledgments}

We thank Mr. Emmanuel Samuel (UCL School of Pharmacy) for his help with the mass spectrometry. We also thank Commonwealth Scholarship for the financial support to Awo Afi Kwapong.

\section{A Supplementary data}

Supplementary data associated with this article can be found, in the online version, at https://doi.org/10.1016/.tetlet.2018.04.028.

\section{References}

1. S.S. Gokavi, N.G. Malleshi and M. Guo, Plant Foods Hum Nutr 59, 2004, 105-111.

2. I.A. Nehdi, H. Sbihi, C.P. Tan and S.I. Al-Resayes, Bioresour Technol 126, 2012, 193-197.

3. S. Sharma, N. Agarwal and J. Indian, Nat Prod Resour 2, 2011, 292-297.

4. H.J. Kloos, Ethiopian Pharm Assoc 2, 1976, 18-28.

5. P.C.M. Jansen, In: G.J.H. Grubben and O.A. Denton, (Eds.), Plant Resources of Tropical African 2. Vegetables, 2004, PROTA Foundation/Backhuys Publishers; Wageningen, Netherlands, 365-367.

6. M.H. Ghante, S.L. Badole and S.L. Bodhankar, In: V.R. Preedy, R.R. Watson and V.B. Patel, (Eds.), Nuts and seeds in health and disease prevention, 2011, Academic Press; United States of America, 521-526.

7. M. Eddouks, M. Maghrani, N.A. Zeggwagh and J.B. Michel, J Ethnopharmacol 97, 2005, 391-395.

8. M. Maghrani, N.A. Zeggwagh, J.B. Michel and M. Eddouks, J Ethnopharmacol 100, 2005, 193-197.

9. R.G. Mali, S.G. Mahajan and A.A. Mehta, Orient Pharm Exp Med 7, 2007, 331-335.

10. U.H. Maier, H. Gundlach and M.H. Zenk, Phytochemistry 49, 1998, 1791-1795.

11. L.B. Rice and R.A. Bonomo, In: V. Lorian, (Ed), Antibiotics in laboratory medicine, 2005, Lippincott Williams \& Wilkins; USA, 483-484.

12. C.E. Alvarez-Martinez and P.J. Christie, Microbiol Mol Biol Rev 73, 2009, 775-808.

13. E.L. Zechner, S. Lang and J.F. Schildbach, Philos Trans R Soc Lond B Biol Sci 367, 2012, 1073-1087.

\section{A Supplementary data}

Multimedia Component 1

Supplementary data 1

Graphical abstract 
Highlights

- A new dimeric imidazole alkaloid was isolated from the seeds of Lepidium sativum

- Structure elucidation was achieved by analysis of the NMR spectroscopic and mass spectral data.

- The new compound, named lepidine AK (1), reduced the conjugal transfer of the Incl 2 plasmid TP114 to $44.7 \%$.

- Interestingly, compound 1 also promoted the conjugation of the IncN plasmid pKM101 to greater than $120 \%$.

- Plasmid transfer inhibitors may have utility in reducing the spread of antibiotic resistance genes and bacterial virulence.

\section{Queries and Answers}

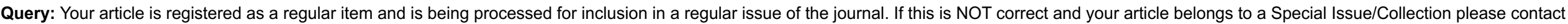
m.r.griffiths@elsevier.com immediately prior to returning your corrections.

Answer: Yes

Query: The author names have been tagged as given names and surnames (surnames are highlighted in teal color). Please confirm if they have been identified correctly. Answer: Yes

Query: The country name has been inserted for the affiliation 'b'. Please check, and correct if necessary.

Answer: Ghana 